\title{
Meningkatkan Kreativitas dan Keaktifan Siswa Dalam Pembelajaran Teks Prosedur Menggunakan Based Learning Melalui Media YouTube Berbasis Video Interaktif
}

\author{
Tasya Almajirah \\ E-mail: tasyaalmajirah18@ gmail.com \\ Program Studi Pendidikan Bahasa dan Sastra Indonesia, Universitas Riau
}

\section{Pengantar}

Perkembangan pendidikan di era digital saat ini memungkinkan peserta didik mampu mendapatkan pengetahuan yang overflow serta cepat tanggap dan mudah di pahami oleh peserta didik. Perubahan di era digital tentunya penting bagi seorang pendidik, sehingga mengharuskan pendidik memiliki kemampuan mengintegrasikan teknologi informasi dan komunikasi ke dalam proses pembelajaran. Pembelajaran inovatif memberikan peluang kepada siswa untuk mengembangkan kompetensi yang dimiliki.

Biasanya, dalam pelaksanaan proses pembelajaran materi teks prosedural dalam mata pelajaran Bahasa Indonesia, penyajian materi terlalu rumit bagi siswa jika hanya dengan sebatas penjelasan pengertian, ciri-ciri, dan memaparkan contoh teks proseduralnya saja tanpa memperagakan/mempraktikkan serta memberikan kesempatan kepada siswa untuk berpikir kritis dan kreatif dalam menguasai suatu materi. Hal ini tentu memerlukan media pembelajaran yang berbasis video untuk memberikan manfaat dalam pembelajaran materi teks prosedural guna meningkatkan semangat, perhatian, dan motivasi siswa,serta meningkatkan efektifitas pembelajaran kepada peserta didik.

Salah satunya, menghadirkan media YouTube guna membantu dan meningkatkan pembelajaran Bahasa Indonesia dengan adanya teks prosedural. Materi teks prosedural ini dapat disajikan melalui aplikasi YouTube dengan melalui model pembelajaran inovatif yang berbasis video sehingga menarik perhatian siswa dan meningkatkan keaktifan dan kreativitas peserta didik di era digital. Selain itu, media pembelajaran berbasis video ini dapat memberikan semangat kepada peserta didik, agar saat pembelajaran dimulai peserta didik tidak merasa bosan. 


\section{a. Model Pembelajaran}

Model pembelajaran inovatif pada Teks Prosedur memerlukan media dan strategi dalam mewujudkan pelaksanaannya. Di era pandemi sekarang ini, pihak sekolah memutuskan dalam proses belajar mengajar dilaksakan melalui sistem daring (Dalam Jaringan). Dalam kontek belajar daring di masa covid-19, kualitas belajar tidak diharapkan menurun tetapi terus meningkat. Jika kualitas belajar menurun, maka dapat memberikan dampak mutu capaian belajar wawasan dan pengalamannya (Zulhafizh, Atmazaki, \& Syahrul,2013).

Pembelajaran inovatif berpusat pada keaktifan dan kreativitas siswa. Dalam pembelajaran Inovasi dapat menciptakan berbabagai upaya menarik minat dan motivasi siswa untuk terlibat dalam proses pembelajaran. Dengan adanya minat dan motivasi yang tinggi, serta adanya dorongan dari orang terdekat hal ini juga dapat membantu siswa mencapai pembelajaran yang maksimal (Zulhafizh, A., \& Syahrul 2013). Dengan demikian, pembelajaran inovatif yang menuntut keaktifan siswa mendorong mereka berpikir kritis dan kreatif dalam membangun dan memahami materi secara mandiri.

Terkait dengan hal ini, maka kita dapat memanfaatkan fasilitas teknologi informasi dan komunikasi menggunakan Pembelajaran Based Learning (PBL) melalui media YouTube yang berbasis video interaktif. Dengan demikian, peserta didik akan tertarik dengan hadirnya media YouTube yang dapat membantu proses belajar peserta didik jarak jauh, sehingga mudah di pahami oleh peserta didik dengan adanya tutorial, langkah-langkah atau tahap menyelesaikan suatu aktivitas yang disebut dengan prosedur.

\section{b. Teks Prosedur}

Teks prosedur merupakan teks yang berisi langkah-langkah atau tahapan yang harus ditempuh dalam menyelesaikan suatu aktivitas. Untuk memahami lebih jelas, sikatan bahwa dalam pembelajaran Teks prosedur berisikan beberapa tahapan yang disusun secara informatif menggunakan tahapan yang berkelanjutan dengan penjelasan bersifat logis, aktual dan akurat. Dalam mengerjakan suatu aktivitas atau kegiatan menggunakan teks prosedur biasanya tidak dapat diubah-ubah urutannya. Karena hal tersebut perlu mengadakan observasi terlebih dulu, sehingga mendapatkan penjelasan yang bersifat logis, aktual dan akurat tersebut. Setelah 
mengadakan observasi pendidik akan bisa mihat dan menilai peserta didiknya meskipun dari jarak jauh.

Namun, saat ini masih ada dijumpai beberapa guru yang masih menggunakan pembelajaran konvensional yang berpusat pada pengetahuan guru tanpa melibatkan siswa membangun pemahamannya secara mandiri. Sehingga dalam pelaksanaan proses pembelajaran, penyajian materi menjadi monoton, dan akan membuat peserta didik menjadi jenuh. Salah satunya, penyajian materi teks prosedur dengan sebatas penjelasan pengertian, ciri-ciri, dan contoh tanpa merangsang siswa untuk berpikir kritis dan kreatif dalam menguasai materi (Hidayat, 2017).

Dalam proses belajar mengajar tentu seorang pendidik menjumpai beberapa peserta didiknya yang merasa kesulitan dalam kaitannya dengan menulis prosedur atau memahami bagaimana cara menyelesaikan suatu materi pembelajaran yang akan dikerjakan. Hal ini perlu dorongan dari seorang pendidik untuk menggunakan berbagai metode pengajaran yang bervariatif, salah satunya menggunakan media digital. Oleh karena itu, dengan adanya metode yang tepat digunakan oleh seorang guru/pendidik akan memudahkan para peserta didik, sehingga siswanya juga tidak akan gagal paham.

\section{c. Media YouTube}

Pesatnya media teknologi informasi dan komunikasi seperti media YouTube sangat bermanfaat, hal ini guna membantu dan meningkatkan Pembelajaran Based Learning pada teks prosedural melalui media berbasis video. Materi teks prosedural ini dapat disajikan melalui aplikasi YouTube dengan melalui model pembelajaran inovatif yang berbasis video sehingga menarik perhatian siswa dan meningkatkan keaktifan dan kreativitas peserta didik di era digital.

Dengan pemanfaatan YouTube, siswa akan lebih tertarik untuk memahami suatu materi maupun pengetahuan. Oleh karena itu, melalui media pembelajaran menggunakan YouTube ini, siswa/peserta didik akan lebih cepat tanggap dalam mencermati pembelajaran dibandingkan mempelajari langsung dari penjelasan seorang pendidik. Karena biasanya, media pembelajaran dapat dibuat dan disajikan dengan sekreatif mungkin dan menarik, sehingga peserta didik tidak akan merasa jenuh seperti hal tersebut. 


\section{Langkah-langkah Implementasi Pembelajaran Teks Prosedur Menggunakan YouTube}

Implementasi pembelajaran teks prosedur menggunakan Pembelajaran Based Learning melalui media digital dengan tahap pelaksanaan sebagai berikut:

1. Guru membuat sebuah grup WhatsApp sebagai wadah komunikasi dengan seluruh siswa dan mengarahkan siswa untuk bergabung kedalam grup yang telah disediakan.

2. Setelah grup dibentuk, guru menyiapkan materi pembelajaran baik berupa PPT, bahan bacaan, atau sumber lainnya yang dapat dijadikan sumber belajar bagi siswa.

3. Beberapa saat sebelum jam pelajaran dimulai, guru menyiapkan tautan media pembelajaran jarak jauh untuk pertemuan secara virtual baik melalui aplikasi Zoom Meeting, Google Meet, atau aplikasi lain yang sejenis.

4. Tautan disebarkan melalui grup yang telah dibentuk tadi.

5. Pembelajaran dimulai setelah seluruh siswa masuk ke tautan yang telah diberikan.

6. Materi pembelajaran tentang teks prosedur disampaikan oleh guru secara virtual dengan penjelasan secara detail yang disertai contoh dan beberapa diskusi mengenai contoh yang diberikan.

7. Setelah penyampaian materi, disediakan ruang pertanyaan kepada siswa jika masih ada pertanyaan seputar materi Teks prosedur.

8. Penyampaian materi pada poin 6-7 juga dapat dilakukan oleh guru dengan membuat video penjelasan singkat mengenai teks prosedur kemudian mengunggah di kanal Youtube sehingga memudahkan siswa jika ingin mengulang penjelasan dari guru. Kemudian untuk sesi pertanyaan dapat dibuka di kolom komentar di kanal Youtube.

9. Setelah materi teks prosedur telah disampaikan dan dipahami oleh siswa, maka guru memberikan tugas sederhana guna meningkatkan kemampuan siswa.

10. Tugas materi teks prosedur dapat berupa pembuatan video teks prosedur dengan tema yang sudah ditentukan oleh guru seperti contohnya : prosedur pembuatan makanan, prosedur pemakaian alat-alat elektronik sederhana, prosedur pembuatan kerajinan tangan sederhana, atau tema lain sesuai dengan kemampuan siswa.

11. Tugas video teks prosedur dapat dilakukan secara berkelompok maupun secara individu oleh siswa yang kemudian diunggah ke kanal youtube pribadi sebagai bahan penilaian oleh guru. 
12. Di akhir sesi pertemuan, guru dapat memberikan contoh teks prosedur dalam menggunakan media sosial Youtube sebagai media pembelajaran agar dapat melatih siswa memahami langkah-langkah secara pasti.

13. Selain itu, guru juga dapat memberikan pelatihan tentang pengoperasian perangkat digital.

\section{Tindakan Solutif}

Dalam mewujudkan pembelajaran inovatif tentu memiliki kemungkinan munculnya berbagai hambatan dalam proses pelaksanaannya. Berikut ini adalah kemungkinan kendala yang muncul beserta solusinya:

1. Signal di berbagai daerah peserta didik tidak menentu.

Solusi : Guru dapat memaklumi dan mencari jalan keluar bersama peserta didik yang bersangkutan. Akan tetapi, seorang guru juga boleh proaktif untuk menghubungi siswa dan orang tua siswa secara personal. Agar ketidak hadiran siswa itu jelas, kemudian guru memberikan arahan serta pendampingan agar siswa tetap bisa mengikuti pelajaran tanpa harus mengikuti kelas daring apabila benar-benar terkendala jaringan.

2. Kuota internet tidak mencukupi

Solusi : Guru memaklumi alasan dari peserta didik. Sebab, pembelajaran jarak jauh memang menguras pengeluaran untuk kuota Internetan ditambah lagi dengan banyaknya mata pelajaran yang berkelanjutan dihari yang sama.

\section{Simpulan}

Model pembelajaran inovatif dalam materi Teks Prosedur Menggunakan Based Learning Melalui Media YouTube adalah model pembelajaran inovatif yang berbasis video interaktif. Media pembelajaran berbasis video ini dapat memberikan semangat kepada peserta didik, agar saat pembelajaran dimulai peserta didik tidak merasa bosan.

Dalam pembelajaran inovatif ini, seorang pendidik harus mampu untuk menggunakan berbagai metode pengajaran yang bervariatif, salah satunya menggunakan media digital. Oleh karena itu, dengan adanya metode yang tepat digunakan oleh seorang guru/pendidik akan memudahkan para peserta didik, sehingga siswanya juga tidak akan gagal paham. 
Model pembelajaran inovatif dalam materi Teks Prosedur Menggunakan Based Learning Melalui Media YouTube ini sangat penting agar ide inovatif ini dapat tersalurkan dan meningkatkan kemampuan peserta didik dalam menggali informasi-informasi penting yang diperoleh terutama dalam bidang pendidikan. Informasi tersebut dapat diperoleh melalui berita, media sosial dan lainnya. Sehingga dapat meningkatkan kemampuan siswa melalui teks prosedur yang bertujuan untuk dapat memahami metode langkah demi langkah secara pasti dalam memecahkan suatu masalah. Selain itu, juga dapat mempermudahkan peserta didik dalam upaya tahap kegiatan untuk menyelesaikan suatu aktivitas. 


\section{Referensi}

Zulhafizh. (2020). Membina Aktivitas Belajar Mahasiswa di Perguruan Tinggi Melalui Metode TIE (Translation, Interpretation, Extrapolation) pada Masa Pandemi Covid-19. Jurnal Kependidikan: Jurnal Hasil Penelitian dan Kajian Kepustakaan di Bidang Pendidikan, Pengajaran dan Pembelajaran, 6(3), 502-511.

Zulhafizh, Atmazaki, \& Syahrul, R. (2013). Kontribusi Sikap dan Motivasi Belajar Siswa terhadap Hasil Belajar Bahasa Indonesia. Jurnal Bahasa, Sastra dan Pembelajaran, 1(2), $13-28$.

Hidayat, N. (2017). Pengaruh Media Gambar Terhadap Kemampuan Menulis Pantun Pada Siswa Kelas Vii Mts Al- Mursyidiyyah Pamulang, Tangerang Selatan Tahun Pelajaran 2016/2017. Skripsi

Hidayat, M. T. (2020). Pembelajaran Menulis Teks Prosedur Dengan Metode Discovery Learning Pada Siswa Kelas Vii Smp Negeri 1 Langsa. 3(3), 45-51. 


\section{Data Penulis}

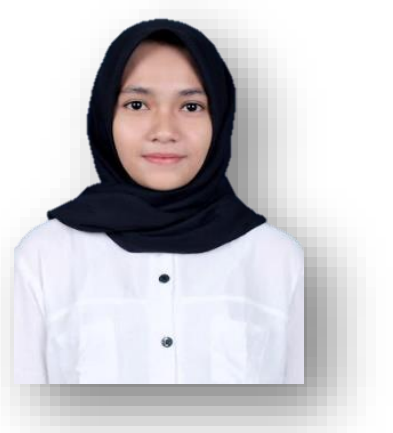

Tasya Almajirah, lahir di Pekanbaru, 18 Januari 2001. Pada tahun akademik 20202021, ia melanjutkan studi pada strata satu Jurusan Pendidikan Bahasa dan Seni di Program Studi Pendidikan Bahasa dan Sastra Indonesia FKIP Universitas Riau melalui jalur PBUD (Penulusuran Bibit Unggul Daerah). Prestasi yang pernah diraih adalah Meraih Harapan 3 Lomba Cipta Tulis Bulan Bahasa 2020 seIndonesia.

Kontak:

Hp/WA : 082278042311

Email : tasyaalmajirah18@gmail.com 